\title{
Leitura comunitária da paisagem em uma cidade média, Santa Maria, RS, Brasil
}

\author{
Lectura comunitaria del paisaje en una ciudad media, Santa \\ Maria, RS, Brasil
}

\section{Community landscape reading in a medium-sized city, Santa Maria, RS, Brazil}

\author{
Filipe Bassan Marinho Maciel \\ filipebassan@gmail.com \\ Universidade Federal de Santa Maria, UFSM, Santa Maria, RS \\ Auriele Fogaça Cuti \\ aurielefc@gmail.com \\ Universidade Federal de Pelotas, UFPel, Pelotas, RS \\ Luis Guilherme Aita Pippi \\ guipippi3@gmail.com \\ Universidade Federal de Santa Maria, UFSM, Santa Maria, RS
}

\begin{abstract}
Resumo: O problema de pesquisa é a identificação dos elementos significativos para os usuários na paisagem de uma cidade média, visando impulsionar um planejamento urbano participativo e democrático. O objetivo é identificar como os atores sociais de um bairro de cidade média percebem os valores, memórias e preferências na paisagem, evocados a partir de seus elementos. Através da técnica de Mosaico da Paisagem (painel visual e questionário) foram identificados os lugares mais significativos dentro do bairro Camobi. A leitura comunitária pode vir a fortalecer o planejamento urbano democrático do bairro, já que foi evidenciado o que os habitantes reconhecem como significativo para sua comunidade, ou seja, elementos que devem permanecer e serem valorizados na paisagem.
\end{abstract}

Palavras-chave: espaços urbanos; diagnóstico; planejamento participativo.

Resumen: El problema de investigación es la identificación de los elementos significativos para los usuarios en el paisaje de una ciudad media, para promover una planificación urbana participativa y democrática. El objetivo es identificar cómo los actores sociales de un barrio de una ciudad media perciben los valores, memorias y preferencias en el paisaje, evocados a partir de sus elementos. Así, se desarrolló la técnica del Mosaico del Paisaje (panel visual y cuestionario) para identificar los lugares más significativos dentro del barrio Camobi. La lectura comunitaria puede fortalecer la planificación urbana democrática del barrio, ya que se evidenció lo que los habitantes reconocen como significativo para su comunidad, es decir, elementos que deben permanecer y ser valorados en el paisaje.

Palabras clave: espacios urbanos; diagnóstico; planificación participativa. 
Abstract: This research intends to identify significant elements for users in the landscape of a medium-sized city, aiming to promote participatory and democratic urban planning. The goal is to identify how the social actors of a district perceive the values, memories, and preferences in the landscape, evoked from its elements. Through the technique of Landscape Mosaic (visual panel and questionnaire), it was identified as the most significant place within the Camobi District. Community reading can strengthen the neighborhood's democratic urban planning since it was evidenced by what the inhabitants recognize as significant for their community, that is, elements that must re-main and be valued in the landscape.

Keywords: urban spaces; diagnosis; participatory planning.

\section{INTRODUÇÃO}

A análise de contexto antecede qualquer proposição arquitetônica, urbanística e/ ou paisagística, sendo o diagnóstico uma ferramenta importante para a compreensão da problemática em que se insere uma intervenção. As mudanças socioeconômicas causadas pela Revolução Industrial levaram à urbanização acelerada e à lotação das cidades no século XIX. A inexistência de transporte público de massa e a necessidade de que os trabalhadores pudessem ir a pé ao trabalho induziram a densificação do entorno das fábricas, conformando um ambiente insalubre para moradia (CARMONA et al., 2010). Na primeira metade do século XX, o Modernismo reagiu às condições físicas da cidade industrial, valendo-se do conhecimento médico desenvolvido à época, o qual apontava para a necessidade de insolação, ventilação e acesso a espaços livres para maior salubridade das edificações. Os novos princípios propostos para as tipologias edificadas buscavam separar as construções umas das outras, espalhá-las para permitir o fluxo de ar desimpedido e a insolação, construindo para o alto, onde a luz e o ar eram abundantes (CARMONA et al., 2010).

A oportunidade e a vontade política para testar essas novas ideias vieram a partir do fim da Segunda Guerra Mundial. Sob a forma de intervenções urbanísticas e políticas de renovação urbana, alguns projetos visavam à reposição completa de grandes áreas do tecido urbano consolidado. Nesse processo, seriam ignorados importantes aspectos, tais como os valores da população e os intensos e longos investimentos sociais e econômicos das comunidades e dos indivíduos no seu ambiente habitacional. Desconsiderou-se a complexidade da vida urbana; o patrimônio histórico; a integração e a inter-relação entre as funções urbanas e atividades humanas; a importância das redes sociais estabelecidas localmente; os valores afetivos, entre outros (DEL RIO, 1990). O mesmo autor aponta que, já nos anos 1960, a população afetada passou a protestar, fomentando a crítica da qualidade do ambiente urbano que vinha sendo produzido. Também alvo de críticas foi o caráter autoritário percebido no Modernismo, que dispensava o diálogo com os usuários para conhecer suas preferências e anseios para os projetos.

Um dos desafios da cidade contemporânea, que vivencia e sente os efeitos negativos da falta e/ou do mau planejamento de décadas passadas, é a promoção da qualidade de 
vida de seus habitantes. Principalmente nos países em desenvolvimento, é necessário abandonar o costumeiro crescimento urbano desregrado, espontâneo, baseado em soluções de curto prazo e não participativo. Uma instância de planejamento que tem sido considerada em alguns municípios brasileiros é o plano de bairro. Esse delimita prioridades para determinados setores da cidade com a participação dos moradores, os quais vivenciam seu bairro de forma mais intensa no dia-a-dia, o que auxilia a reduzir certas limitações impostas pela escala maior no diagnóstico feito pelos técnicos. Nesse sentido, coloca-se como problema de pesquisa: como coletar as percepções comunitárias da paisagem de um bairro, visando à construção de um planejamento urbano participativo e democrático? Logo, o objetivo deste estudo é identificar como os atores sociais de um bairro de uma cidade média percebem os valores, memórias e preferências na paisagem, evocados a partir de seus elementos. Os resultados aqui apresentados fazem referência à primeira aplicação do instrumento de coleta de percepções ocorrida no ano de 2014. Encontra-se em andamento a atualização dessa leitura, a ser realizada de cinco em cinco anos pela equipe de pesquisa, para acompanhamento da evolução da percepção comunitária frente às modificações progressivas na paisagem do bairro.

\section{PAISAGEM, IMAGEM E CIDADE}

Santos (2005) define paisagem como um conjunto de elementos naturais e artificiais que caracterizam uma área fisicamente, sendo uma porção territorial passível de ser contemplada pela visão. O autor também traz o aporte do passado e do presente compondo a paisagem, sendo esta a soma de elementos de diferentes tempos e ressalta a importância das pessoas e das suas intervenções no ambiente. Cullen (1993) complementa que a paisagem urbana pode ser definida como o conjunto de elementos, em várias escalas, a relação entre eles e entre o espaço e as edificações. O conjunto dessas relações configura a escala da paisagem na cidade.

A paisagem só existe em relação ao homem, sendo um produto das civilizações. Porteous (1996) apresenta paradigmas sobre a relação do homem com a paisagem, sendo um deles a qualidade visual da paisagem. Essa abordagem é a que trata das variáveis formais que provocam sentidos e tem aplicação direta no planejamento urbano. Para Nasar (1988), a qualidade visual percebida é uma construção psicológica, sendo que envolve avaliações subjetivas. Cada avaliação tem referência no ambiente, nos sentimentos das pessoas sobre o ambiente ou nos seus julgamentos sobre os elementos que o compõem. A paisagem apresenta, portanto, um equilíbrio que precisa ser preservado, isto é, a interrelação de infraestrutura, lote, edificação, usos, elementos da paisagem natural e unidades morfológicas que devem ser equilibradas. Apesar disso, a literatura expõe que a paisagem, ou a identidade paisagística de um lugar, é um problema negligenciado e, assim, deve ser alvo do planejamento (CASTRIOTA, 2009; LYNCH, 1975; YÁZIGI, 2001; ANGEOLETTO et al., 2018; RUMBLE et al., 2019). Para o planejamento urbano, o estudo de como a paisagem é percebida através da imagem avaliativa da cidade pelos seus usuários é fundamental. Isso 
abrange também identificar como as pessoas se apropriam do ambiente, como o utilizam e como se relacionam com ele.

Para Lynch (1997, p. 4), a fisionomia das cidades evoca nas pessoas uma imagem mental do seu ambiente, "produto tanto da sensação imediata quanto da lembrança de experiências passadas, e seu uso se presta a interpretar as informações e orientar a ação". Essa imagem é conformada através de cinco tipos de elementos físicos perceptíveis nas formas urbanas - vias, limites, bairros, pontos nodais e marcos - mas sofre influência também do "significado social de uma área, sua função, sua história, ou mesmo seu nome" (LYNCH, 1997, p. 51). Del Rio (1990, p. 96) enfatiza que a importância da imagem reside “no fato que a população busca perceber lugares familiares em seu ambiente construído que estejam carregados de memórias significativas e que possam gerar-lhes estabilidade psíquica e social".

A dimensão simbólica do espaço urbano assume-se, enquanto local de vivências, através da tradução de "crenças, valores e mitos" em formas espaciais: "monumentos, lugares sagrados, uma rua especial etc.", que não têm os mesmos valores para as diferentes classes sociais (CORRÊA, 1989, p. 9). Conforme apontam Carmona et al. (2010), a percepção envolve a reunião, a organização e a interpretação da informação apreendida do ambiente. Indivíduos diferentes expostos aos mesmos estímulos sensoriais de um ambiente reagem, organizam e avaliam a informação recebida de forma distinta. Tendo em vista a abrangência envolvida na apreensão das paisagens urbanas, não basta descrevê-las: "o desafio contemporâneo é procurar compreender as complexas relações que as conformam, movimentam, transformam e engendram identidades, conflitos, representações, apropriações, ideologias" (SCHLEE et al., 2009, p. 38).

\section{METODOLOGIA}

O trabalho apresenta ambas as abordagens qualitativa e quantitativa, e nível exploratório em relação ao objetivo proposto, obtidos com o instrumento denominado Mosaico da Paisagem, em alusão a um conjunto de pequenos fragmentos que reconstroem a imagem da paisagem. Desenvolvido para identificar os valores, a memória e a preferência dos atores sociais de um bairro, esse instrumento consiste em: (a) painel visual, composto por vinte fotografias selecionadas do objeto empírico, e (b) questionário com perguntas de resposta aberta, dirigido aos respondentes. As fotografias componentes do painel tiveram como critério de escolha o seu potencial de evocar imagens mentais do bairro, conforme Lynch (1997). Na Figura 1, essas imagens têm dimensões reduzidas a fim de conservar o formato original do mosaico apresentado aos participantes da pesquisa. As mesmas imagens poderão ser visualizadas ampliadas nas figuras 4 a 8 .

Num primeiro momento, foram identificados e caracterizados os principais pontos nodais do objeto empírico, através de pesquisa bibliográfica e visitas exploratórias in loco, para então direcionar a escolha das fotografias. Para Lynch (1997) os pontos nodais constituem a condensação de algum uso ou de alguma característica física ou morfológica, 
como um ponto de encontro numa esquina ou uma praça fechada. Alguns desses pontos nodais podem ser um símbolo de um bairro, seu foco, ou sua síntese. Ao encontro, “liga-se ao conceito de bairro, tendo em vista que os núcleos são os focos intensivos dos bairros, seu centro polarizador" (LYNCH, 1997, p. 52-53). Neste trabalho, cada ponto nodal recebeu uma denominação própria, referente ao principal elemento evocativo de imagem local, geralmente um marco ou caminho. Portanto, mesmo que a sua denominação se refira a um marco, o ponto nodal abrange também seu entorno imediato.

Posteriormente, o painel visual foi apresentado aos moradores do bairro, simultaneamente à aplicação de um questionário. De acordo com Voordt e Wegen (2013), os questionários são adequados quando há um grupo grande e variado envolvido na pesquisa, com seus respondentes colaborando de maneira anônima e voluntária. O painel visual e o questionário foram aplicados durante o período de uma semana no fim do mês de maio de 2014 de duas formas: online, através do recurso de formulários do Google disponibilizado em redes sociais e, também, pessoalmente in loco nos pontos nodais, conformando um total de 142 respostas. A seleção dos respondentes deu-se por disponibilidade e espontaneidade em colaborar com a pesquisa de maneira online e, presencialmente, foi utilizada uma amostra de oportunidade, ou seja, pessoas que estavam nos pontos nodais e que se mostraram dispostas a responder. Foi solicitado aos respondentes que apontassem cinco fotografias do painel que considerassem as mais representativas do bairro analisado. Das cinco fotografias escolhidas, foram citados três aspectos positivos e três aspectos negativos de cada local representado.

Figura 1: Painel visual do Mosaico da Paisagem aplicado ao objeto de estudo.
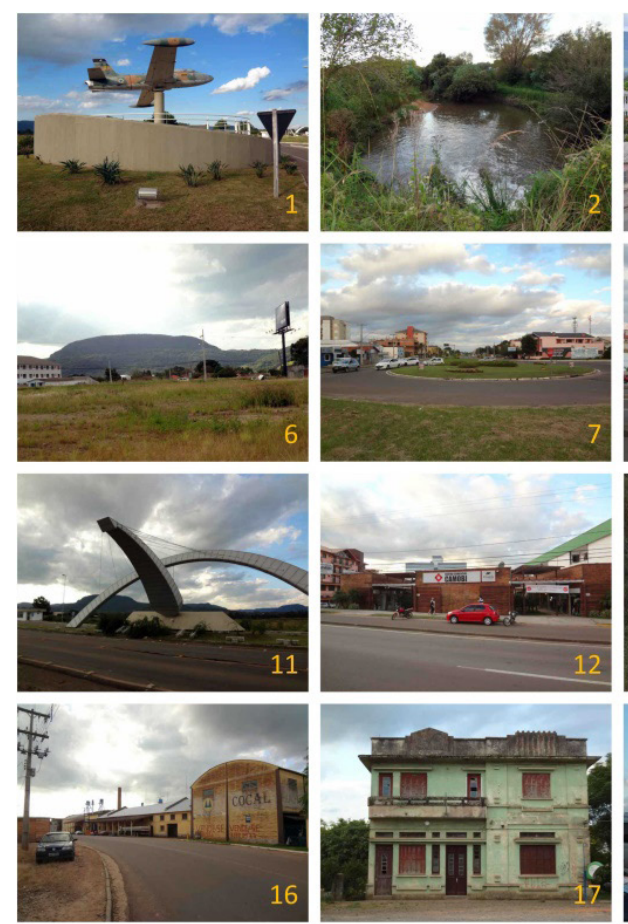
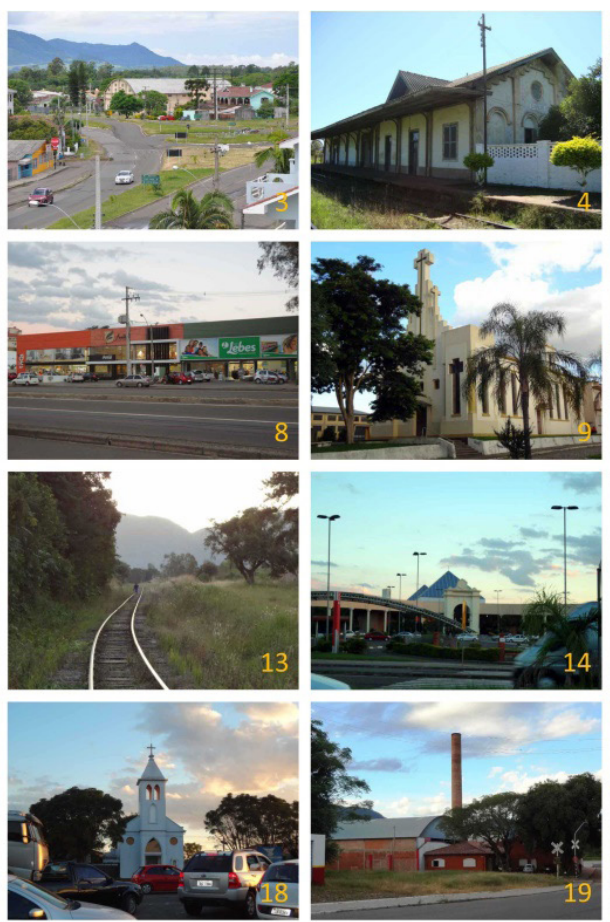

Fonte: Maciel, 2014.
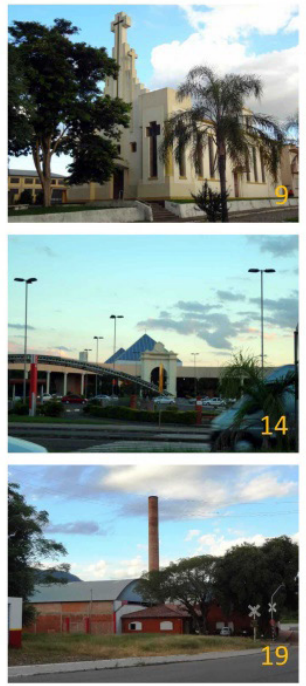

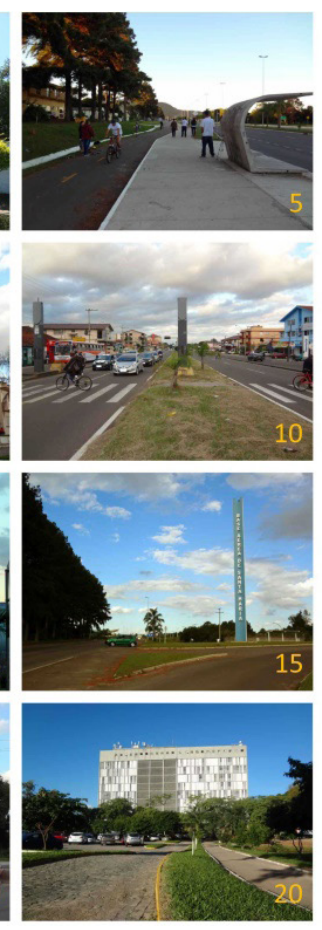


Como o questionário foi constituído por perguntas de respostas abertas, para a tabulação dos resultados agruparam-se os aspectos positivos e negativos citados pelos respondentes em categorias estabelecidas de acordo com as respostas. Por exemplo, se um respondente citasse que percebia um edifício como um elemento antigo da paisagem ou relacionado a um evento importante da história local, essa resposta seria enquadrada na categoria 'valor histórico'. Importante colocar aqui que essa categorização não é fechada, podendo ser utilizadas outras que melhor se adequem à realidade local e aos conceitos ou constructos utilizados em pesquisa. Logo, cada menção de um aspecto foi contabilizada na categoria correspondente, permitindo ranqueá-las. Posteriormente, as categorias relacionadas a lugares específicos retratados no painel visual foram agregadas de acordo com os respectivos pontos nodais, que puderam ser comparados entre si.

\section{CARACTERIZAÇÃO DO OBJETO EMPÍRICO DE ESTUDO}

Nesta pesquisa, a expressão 'cidade média' é utilizada mais em referência ao seu critério demográfico - populações entre 100.000 e 500.000 habitantes, de acordo com a classificação do IBGE (2014) - do que funcional, objetivando situar o contexto analisado em termos de tamanho de sistema socioespacial. No entanto, julga-se importante mencionar que, em países como o Brasil, existe uma diversidade espacial bastante ampla que a denominação 'cidade média' não consegue abarcar. Para o seu entendimento mais profundo, devem ser considerados: o tamanho demográfico, funções, dinâmica intraurbana, intensidade das relações interurbanas e com o campo, indicadores de qualidade de vida e infraestrutura, relações externas e comando regional (SOARES, 2007; ANGEOLETTO et al., 2016).

Nesse sentido, Santa Maria (Fig. 2), localizada na região central do Rio Grande do Sul, enquadra-se na categoria de cidade média, constituindo a quinta maior população absoluta do estado: em 2010 totalizavam 261.027 habitantes e a estimativa para o ano de 2019 é de 282.123 habitantes, representando um crescimento de 8,08\% em nove anos. Em termos de rede urbana, Santa Maria é considerada uma capital regional B, ou seja, um centro relacionado a uma metrópole - Porto Alegre - e que exerce influência de âmbito regional para outras cidades gaúchas - Caçapava do Sul, Cachoeira do Sul, Santiago e São Gabriel sendo referência de destino para um conjunto de atividades (ATLAS SOCIOECONÔMICO DO RIO GRANDE DO SUL, 2018). 
Figura 2: Localização de Santa Maria e do bairro Camobi.

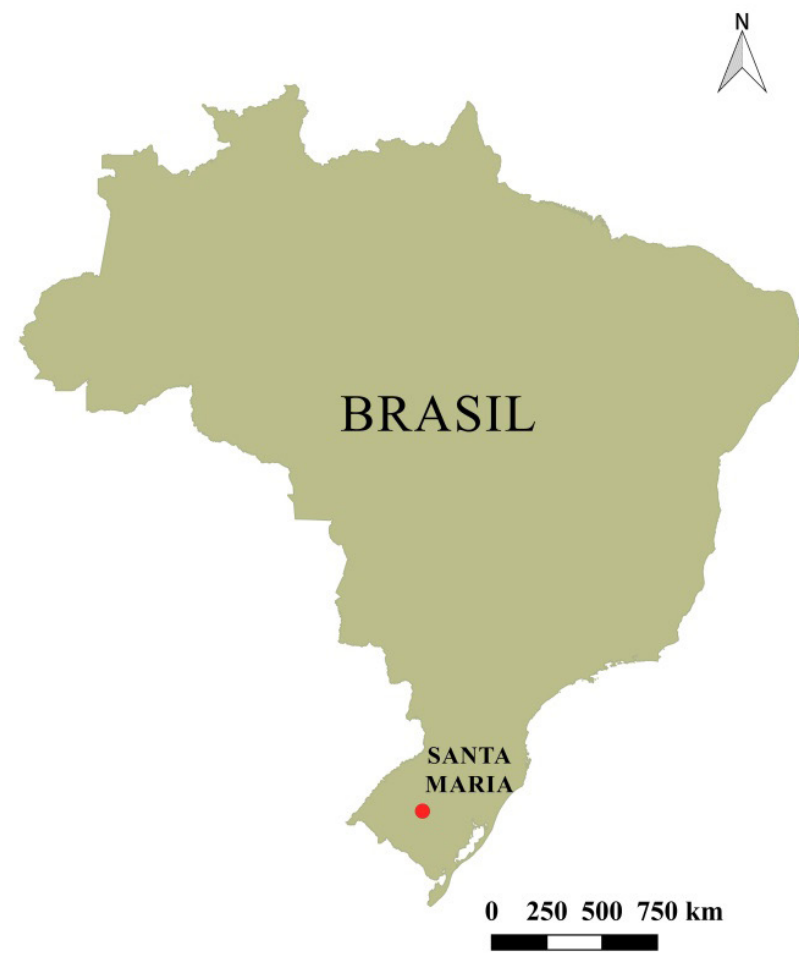

A CIDADE DE SANTA MARIA

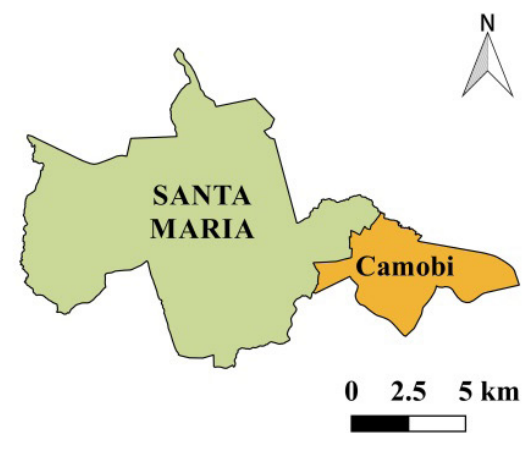

A SEDE URBANA DE SANTA MARIA E O BAIRRO CAMOBI

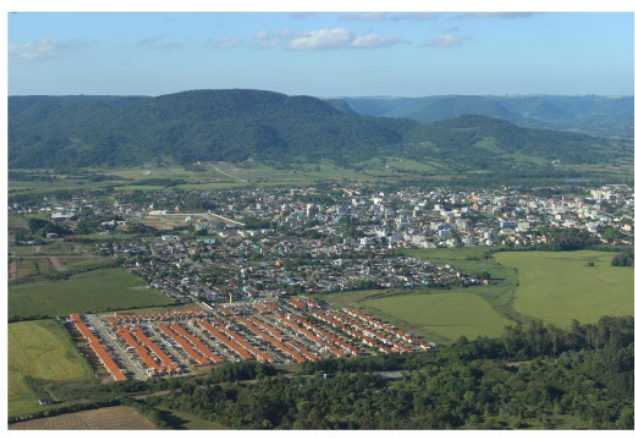

BAIRRO CAMOBI.

Fonte: Acervo Quapá-SEL Núcleo SM, 2015

Fonte: Maciel, 2018.

No contexto do grande crescimento urbano em todas as direções registrado por Santa Maria, merece destaque o caso da zona leste. Até os anos 1950, o atual bairro Camobi era uma pequena vila rural, antigo distrito de Colônia, organizado em torno de sua estação ferroviária. O crescimento do distrito intensificou-se a partir de 1960, quando nele se instalou a primeira universidade pública do interior do Brasil, a Universidade Federal de Santa Maria (UFSM). Essa iniciou o grande impulso imobiliário local, fazendo emergir um núcleo urbano consolidado nas décadas seguintes (SALAMONI, 2008). A partir de 1971, a Base Aérea de Santa Maria juntamente com a universidade, passou a intensificar os fluxos entre o Centro e Camobi.

Segundo a Agência de Desenvolvimento de Santa Maria (2016), o bairro é o maior da cidade em termos de extensão territorial (são 2.035 hectares, correspondendo a 16,7\% do território urbano) e população absoluta (eram 21.822 habitantes em 2010, correspondendo a 8,86\% da população urbana). Contabilizando-se toda a sua extensão territorial políticoadministrativa, Camobi apresenta 10,72 hab./ha., enquanto o Centro da cidade possui 91,52 hab./ha. Assim, o bairro caracteriza-se por baixa densidade demográfica, cerca de 8,5 vezes menor do que a no Centro.

Em termos de forma urbana, há um contraste de grão de parcelamento entre os loteamentos residenciais e as duas grandes áreas institucionais federais do bairro: no campus universitário e na base aérea predominam os vazios sobre os cheios, em função 
da concepção urbanístico-arquitetônica modernista da primeira e pela necessidade de extensa área livre no entorno das pistas do aeródromo da segunda. Os usos do solo predominantes do bairro são os residenciais, com tipos edilícios unifamiliares (geralmente isolados no lote) e multifamiliares de até quatro pavimentos. Há forte presença de comércio e serviços nas imediações das rodovias RS-509 e BR-287, principais eixos de mobilidade, configurando a centralidade local do bairro. Outra característica que vem se consolidando no eixo de expansão urbana centro-zona leste é a instalação de condomínios residenciais fechados, sendo cinco já estabelecidos em Camobi, que impõem problemáticas referentes à conectividade do sistema espacial (MACIEL, 2014; 2018).

Foram identificados cinco pontos nodais em Camobi: Estação Ferroviária, Trevo do Aeroporto, Avenida Roraima, Centro Comercial e Igreja do Amaral (Fig. 3). O ponto nodal Estação Ferroviária (Fig. 4) abrange o centro histórico do bairro, outrora palco da vida social, econômica e religiosa do antigo distrito. Configura-se como ponto nodal pela concentração de edifícios testemunhos da história do bairro, integrantes do imaginário dos moradores, que se encontram desvalorizados e/ ou malconservados. O Trevo do Aeroporto (Fig. 5) corresponde à junção de dois eixos rodoviários estruturadores do bairro, a RS-509 (Faixa Velha) e a RST-287 (Faixa Nova). Configura-se como ponto nodal pela concentração funcional de mobilidade, de e para o qual se dirigem fluxos intrabairro, interbairros e intermunicipais, além de dar acesso à Base Aérea de Santa Maria, ao Aeroporto de Santa Maria e à capital do estado.

Figura 3: Pontos nodais do bairro Camobi.

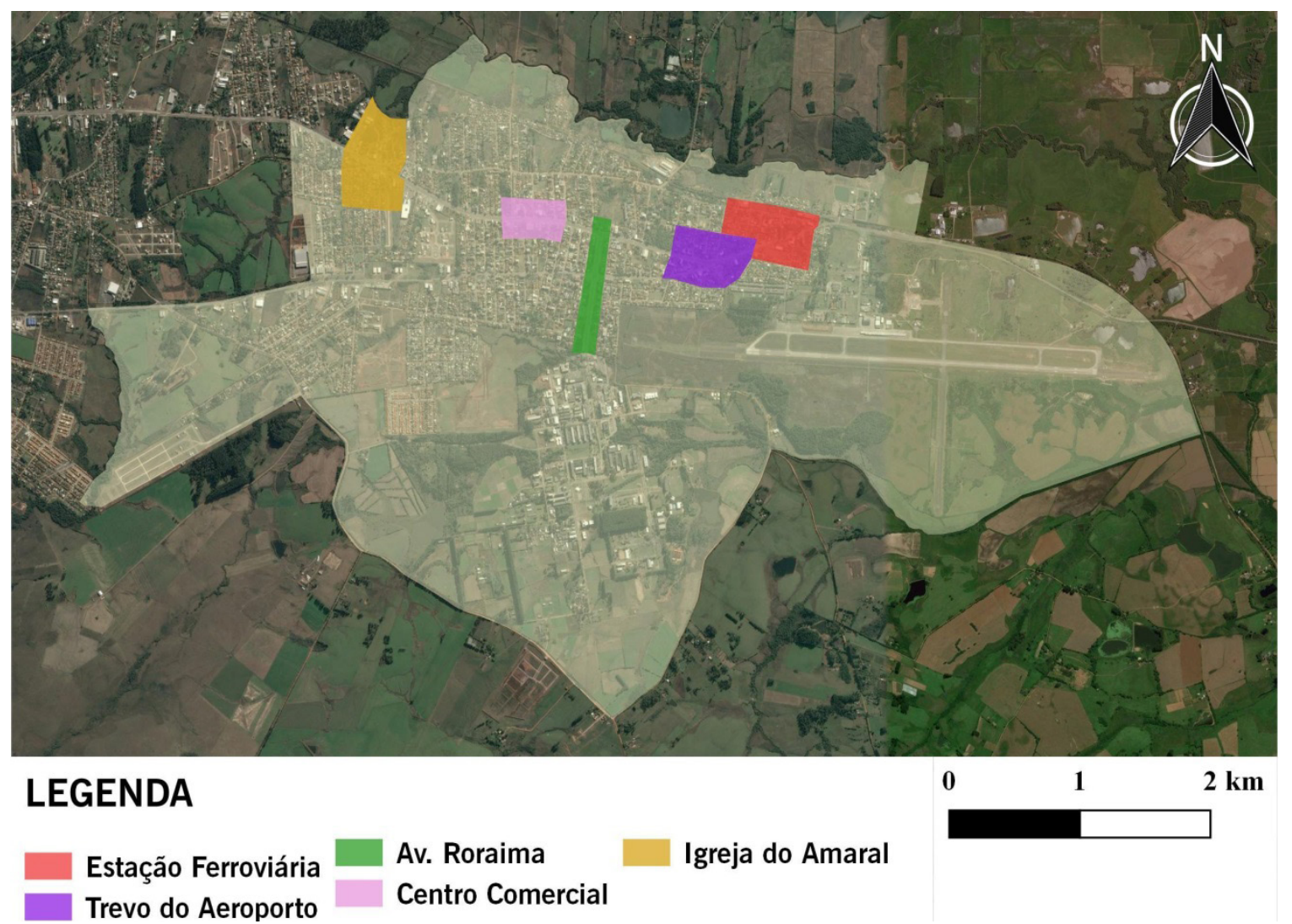

Fonte: os autores. 
Figura 4: Ponto nodal Estação Ferroviária: (A) Estação Ferroviária de Camobi; (B) Igreja Nossa Senhora da Glória; (C) Cooperativa de Arroz Camobi e (D) sobrado em estilo Art Déco.

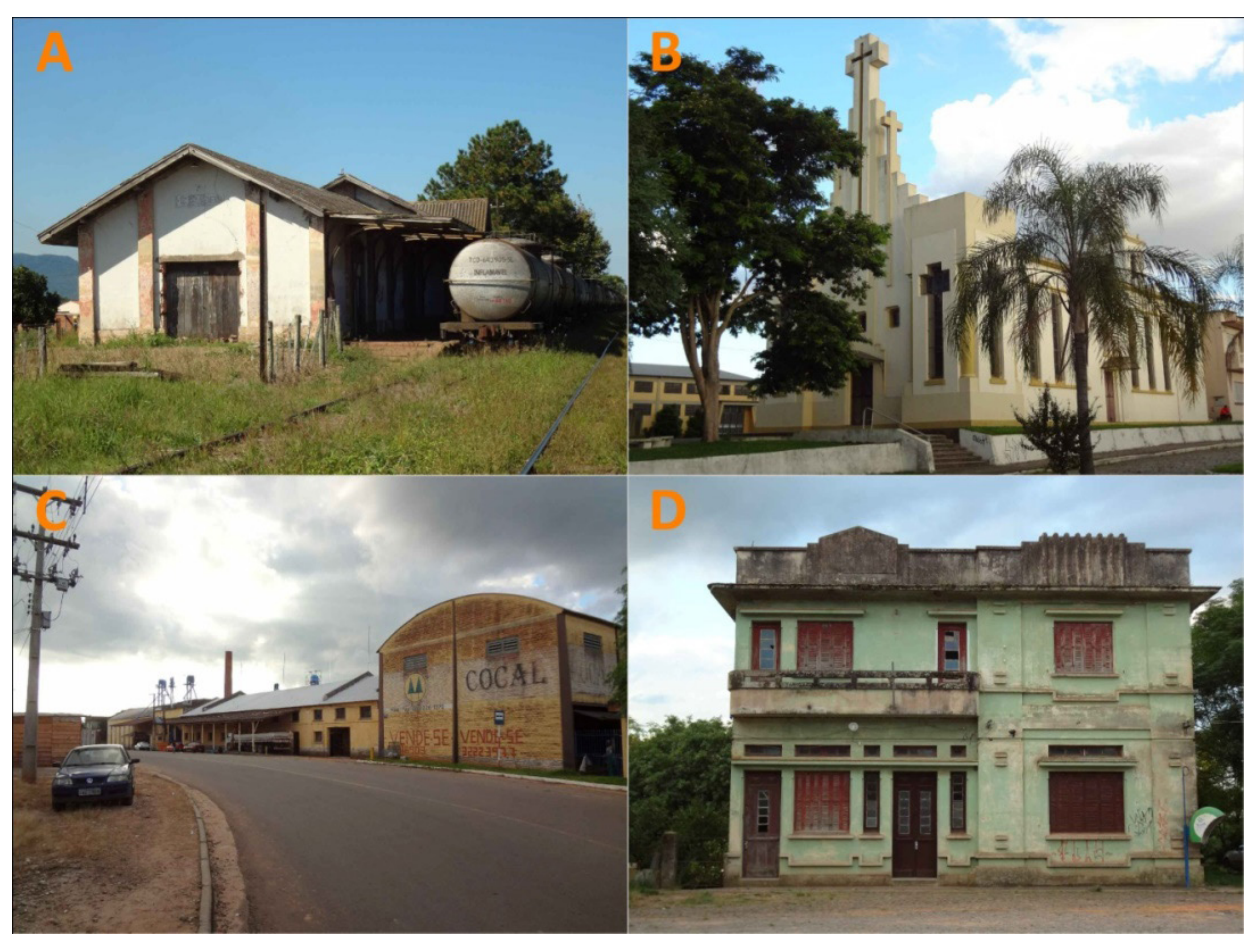

Fonte: Maciel, 2014.

Figura 5: Ponto nodal Trevo do Aeroporto: (A) junção da RS-509 com a RST-287; (B) terreno baldio junto ao trevo; (C) monumento da entrada da cidade, próximo da Base Aérea de Santa Maria; e (D) identificação do acesso ao Aeroporto de Santa Maria.

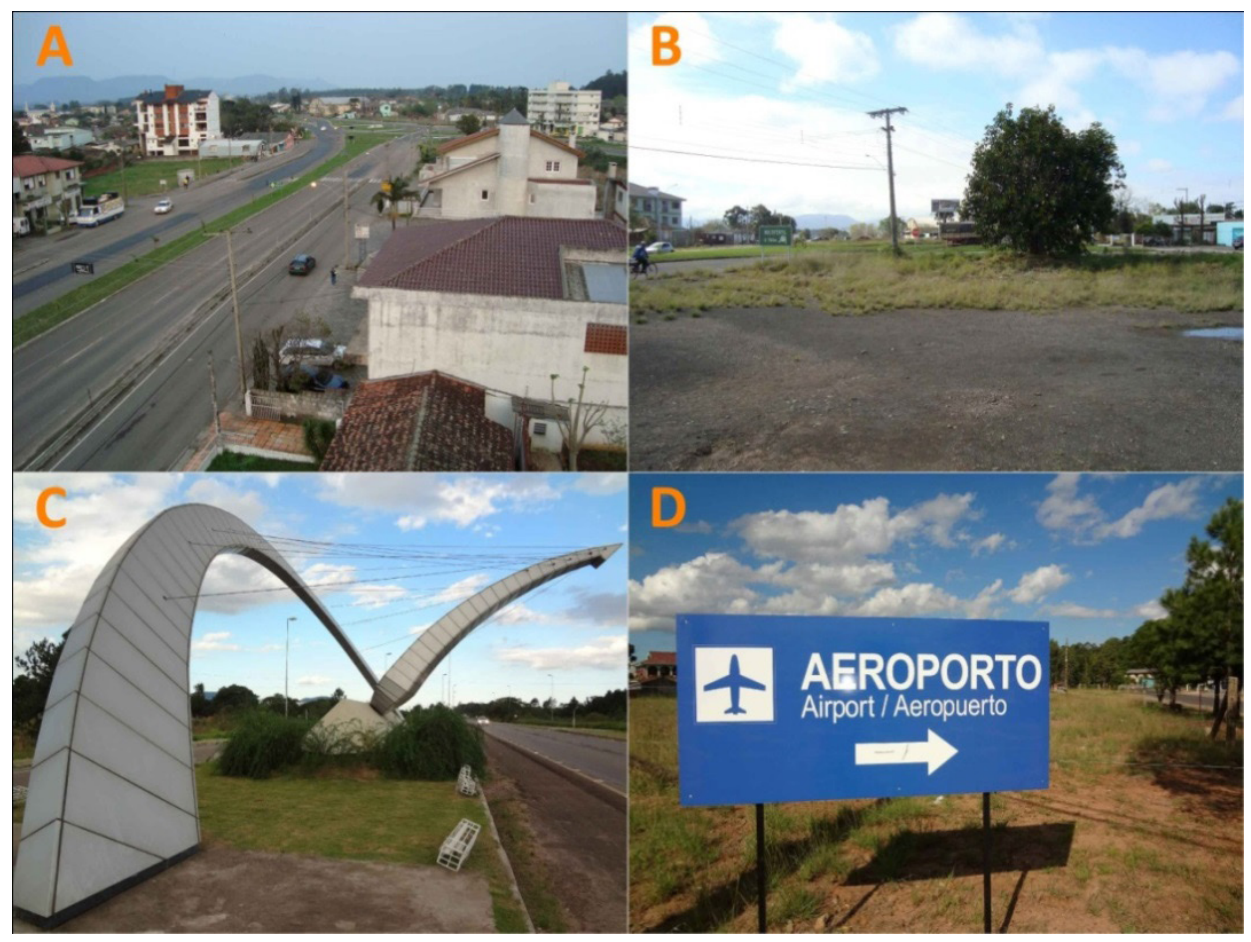

Fonte: Maciel, 2014. 
O ponto nodal Av. Roraima (Fig. 6) engloba o acesso à UFSM, ao Hospital Universitário e ao seu grande espaço livre apreendido como parque e utilizado para lazer e recreação tanto em dias úteis como nos finais de semana. Com a implementação da pista multiuso do campus, a Av. Roraima passou a ser um ponto de convergência de pessoas que se apropriam do espaço para andar de skate, de bicicleta, caminhar, correr, tomar chimarrão e se sentar em cadeiras ou mesmo na grama. O Centro Comercial (Fig. 7) corresponde à área onde se concentram os estabelecimentos comerciais e de serviço no bairro. Nesse ponto nodal há grande risco de conflitos entre os veículos motorizados que circulam pela rodovia e os pedestres que tentam atravessá-la ou que caminham pelo seu leito carroçável devido à ausência de passeio pavimentado. Por fim, o ponto nodal Igreja do Amaral (Fig. 8) corresponde ao entroncamento da RS-509 com a Av. João Machado Soares, acesso oeste de Camobi, na divisa com o bairro Pé de Plátano. Sua característica funcional é semelhante ao Trevo do Aeroporto, com convergência de fluxos em direção ao maior supermercado de Camobi, aos condomínios fechados, aos loteamentos residenciais mais isolados e ao centro da cidade. Soma-se à problemática a desvalorização do recinto histórico da Igreja do Amaral, único edifício religioso localizado na via mais importante do bairro.

Figura 6: Ponto nodal Av. Roraima: (A) apropriação do espaço do passeio e da ciclovia para lazer e recreação; (B) visuais do morro do Elefante; (C) conflitos na mobilidade; e (D) prática de exercícios físicos.

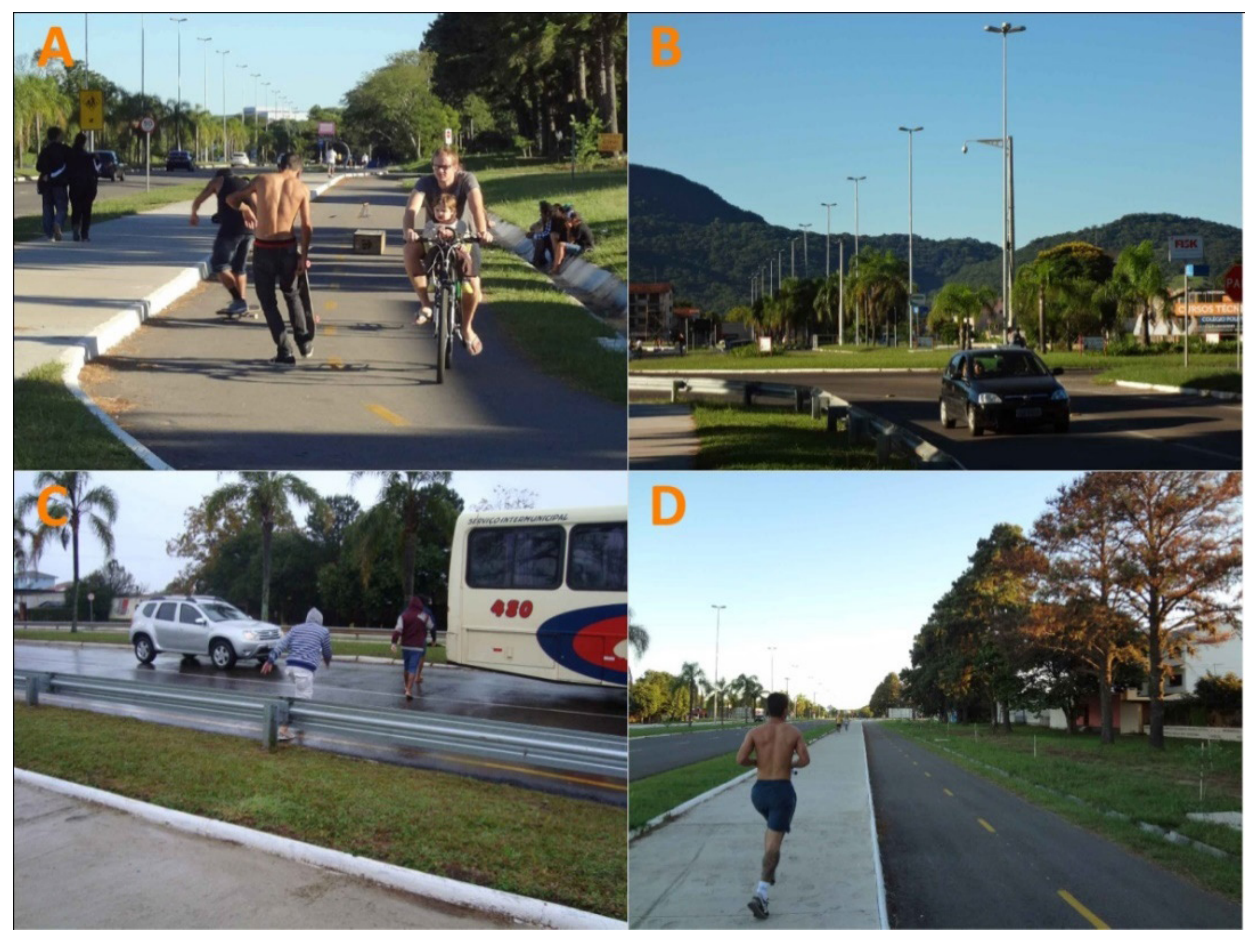

Fonte: Maciel, 2014. 
Figura 7: Ponto nodal Centro Comercial: (A) galeria comercial; (B) estacionamento indisciplinado sobre o passeio; (C) canteiro central da RS-509 com lombada eletrônica, mas sem acessibilidade; e (D) problema de drenagem que causa dificuldades para a mobilidade de veículos e pedestres.

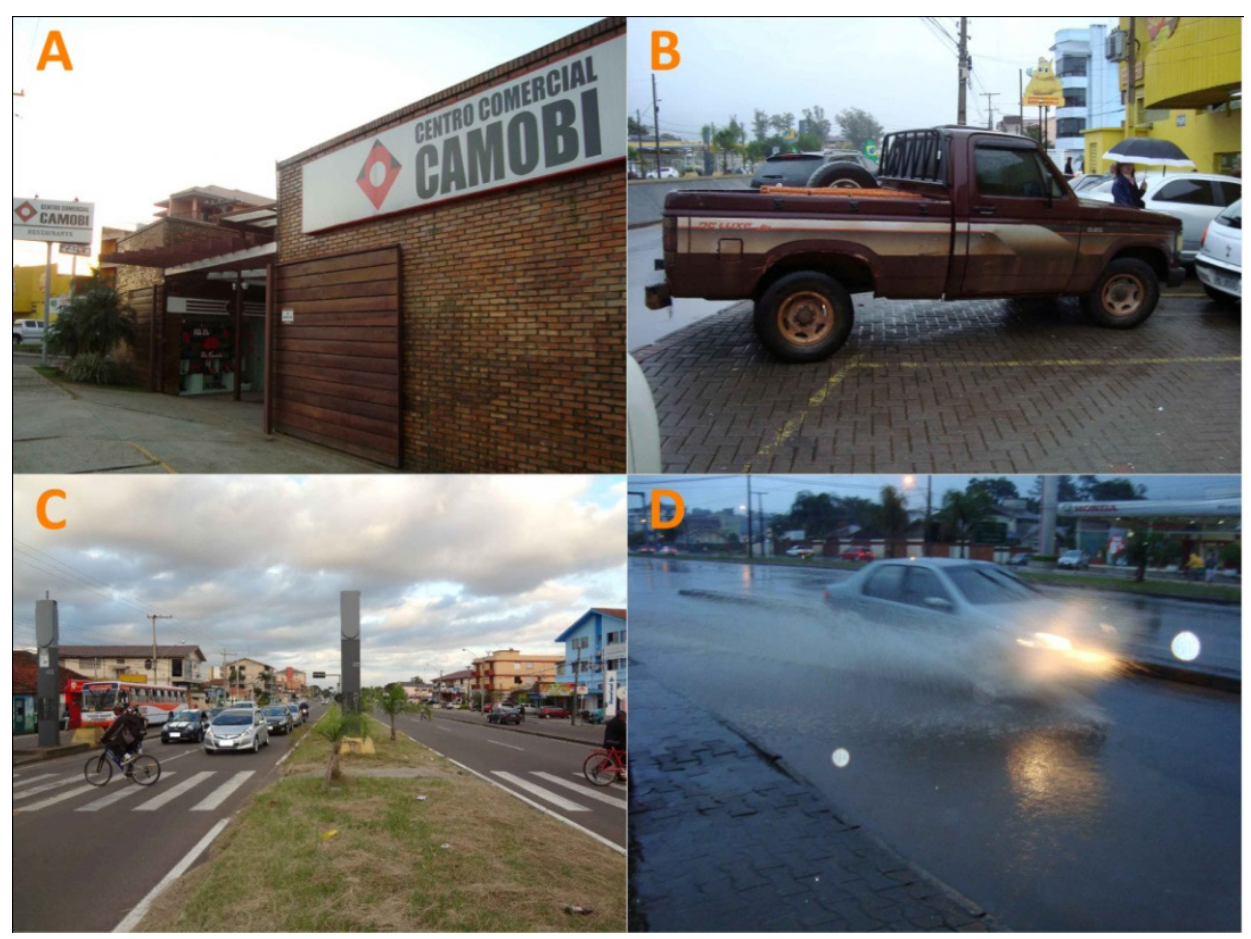

Fonte: Maciel, 2014.

Figura 8: Ponto nodal Igreja do Amaral: (A) Igreja do Amaral; (B) congestionamento de veículos nos horários de pico do trânsito; (C) muros de condomínio residencial fechado; e (D) trechos de passeios sem pavimentação.

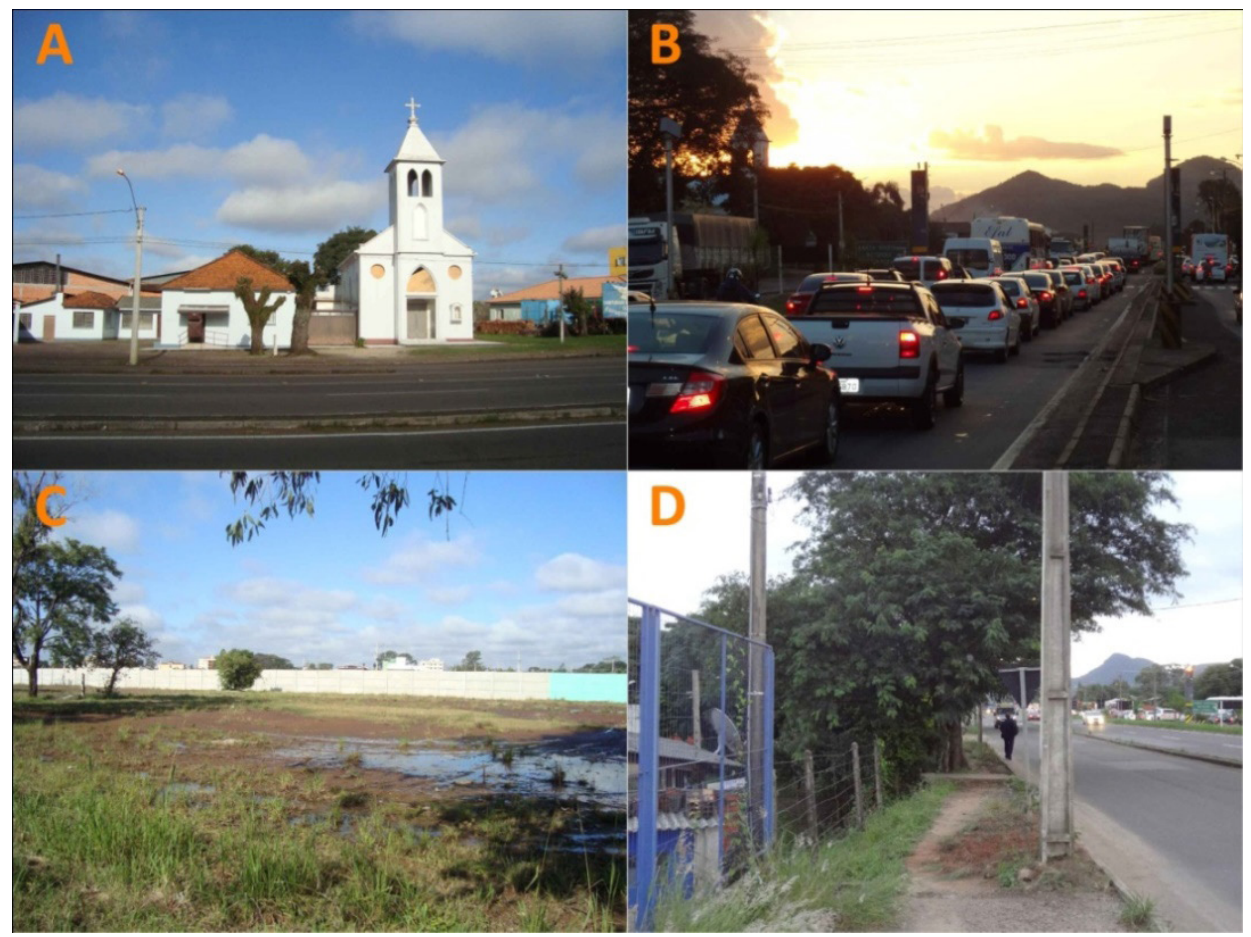

Fonte: Maciel, 2014. 


\section{RESULTADOS}

Dentre os lugares mais representativos de Camobi (Fig. 9), os respondentes apontaram como principais a UFSM (15\%), a Base Aérea de Santa Maria (12\%), Av. Roraima (11\%) e a Estação Ferroviária de Camobi (8\%). Esses são os lugares com maior valor histórico e que apresentam relação direta com o desenvolvimento e a expansão do bairro, de acordo com a pesquisa bibliográfica anteriormente realizada. De acordo com as respostas fornecidas no questionário, foram estabelecidas as categorias de aspectos positivos e negativos. Após essa categorização, foram analisadas as percepções para cada ponto nodal.

Figura 9: Ranking da escolha dos lugares mais representativos de Camobi.

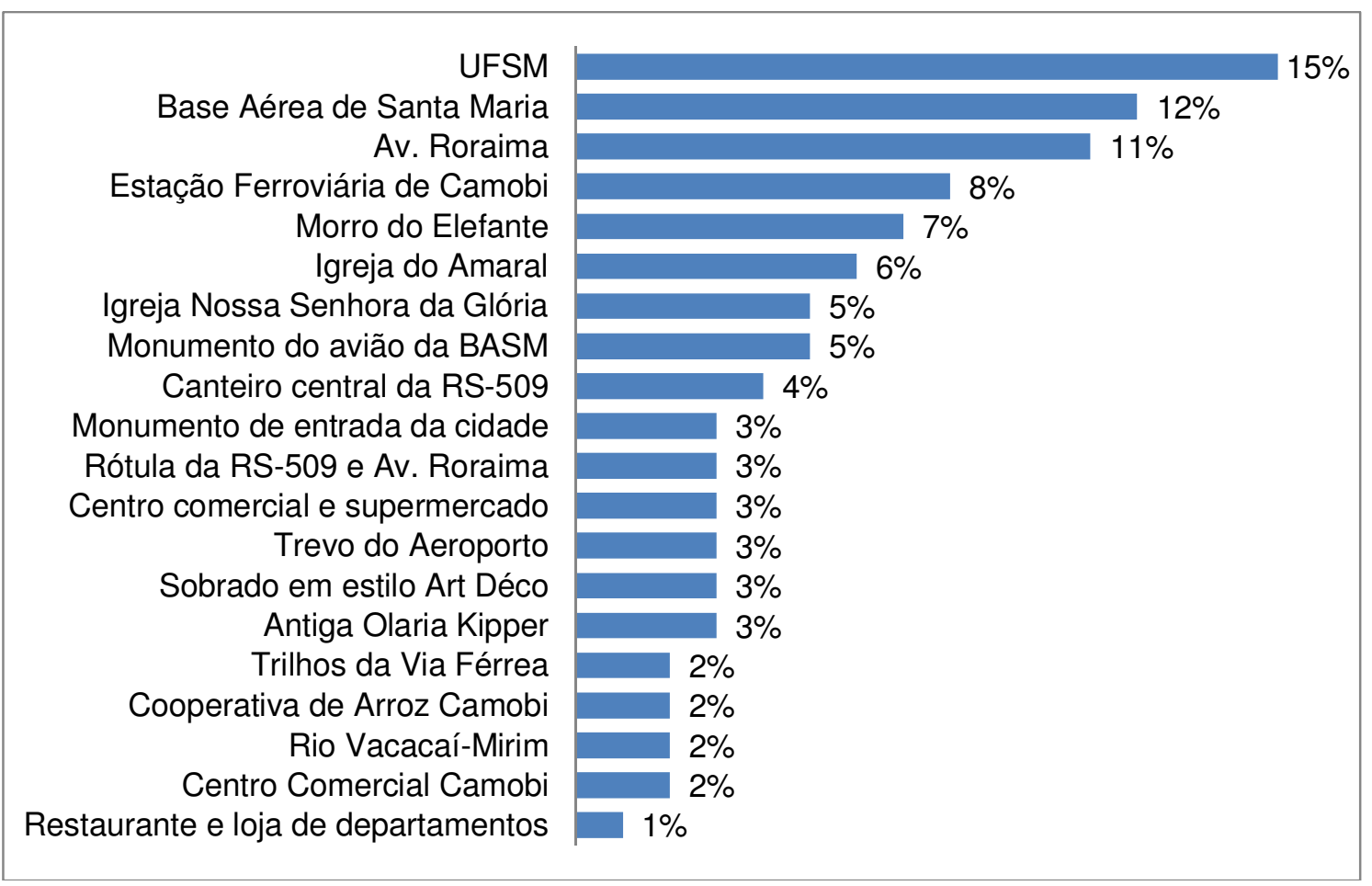

Fonte: os autores.

\section{Estação Ferroviária}

Esse ponto nodal está diretamente ligado a um aspecto simbólico e histórico da cidade, seu conjunto arquitetônico ferroviário, datado do final do século XIX e início do XX. A leitura comunitária (Fig. 10) reconhece essa característica quando aponta como aspectos positivos mais relevantes do ponto nodal o valor histórico $(30,2 \%)$, o valor de memória (21\%) e o valor simbólico (9,6\%). Os aspectos negativos mais representativos da área foram o abandono $(23,5 \%)$, a má conservação (21\%) e a pouca exploração paisagística $(17 \%)$. Destacam-se algumas citações relativas ao principal aspecto positivo - valor histórico - tais como: "ambiente cheio de história e importante para o bairro Camobi e para a cidade" [Estação Ferroviária]; "deve ser carinhosamente preservada, com suas reais características" [Estação Ferroviária]; "foi construído para ser um hotel, uma pousada para hospedar os viajantes de trem" 
[Sobrado em estilo Art Déco]; "indústria importante para o desenvolvimento de Camobi” [Antiga Olaria Kipper]; "tão antigo quanto Camobi" [Cooperativa de Arroz Camobi]; "a Igreja Nossa Senhora da Glória e a praça que fica em frente fazem parte da história do bairro, configurando um núcleo com a estação e a cooperativa". Já para o principal aspecto negativo, o abandono, os comentários foram "Edificação fantasma, sem uso e que poderia servir a população de alguma maneira" [Estação Ferroviária]; "descomprometimento da população e do poder público com esse recurso" [Rio Vacacaí-Mirim]; "a vida social do bairro foi deslocada para a área comercial da Faixa Velha"; "à noite, passar por ali é como passar numa cidade fantasma, caráter reforçado pelo sobrado, pela praça escura da igreja e pela estação" [Cooperativa de Arroz Camobi].

Figura 10: Ranking de aspectos positivos (azul) e negativos (vermelho) do ponto nodal Estação Ferroviária.

\begin{tabular}{|c|c|}
\hline $\begin{array}{r}\text { Abandono } \\
\text { Má conservação } \\
\text { Pouco explorado paisagisticamente } \\
\text { Dificuldade de leitura do lugar } \\
\text { Insegurança (criminalidade) } \\
\text { Risco à integridade ecológica } \\
\text { Fim de atividades no local } \\
\text { Falta de acessibilidade } \\
\text { Insegurança (tráfego) } \\
\text { Não tem aspecto negativo } \\
\text { Falta de continuidade física } \\
\text { Falta de visibilidade } \\
\text { Valor histórico } \\
\text { Valor de memória } \\
\text { Valor simbólico } \\
\text { Valor estético } \\
\text { Valor arquitetônico e/ou urbanístico } \\
\text { Potencial de utilização } \\
\text { Valor religioso } \\
\text { Marco referencial } \\
\text { Lugar de encontro social } \\
\text { Eventos institucionais } \\
\text { Mobilidade motorizada } \\
\text { Áreas verdes } \\
\text { Valor sócio-cultural } \\
\text { Elemento natural da paisagem } \\
\text { Mobilidade não-motorizada } \\
\text { Ambiência agradável }\end{array}$ & 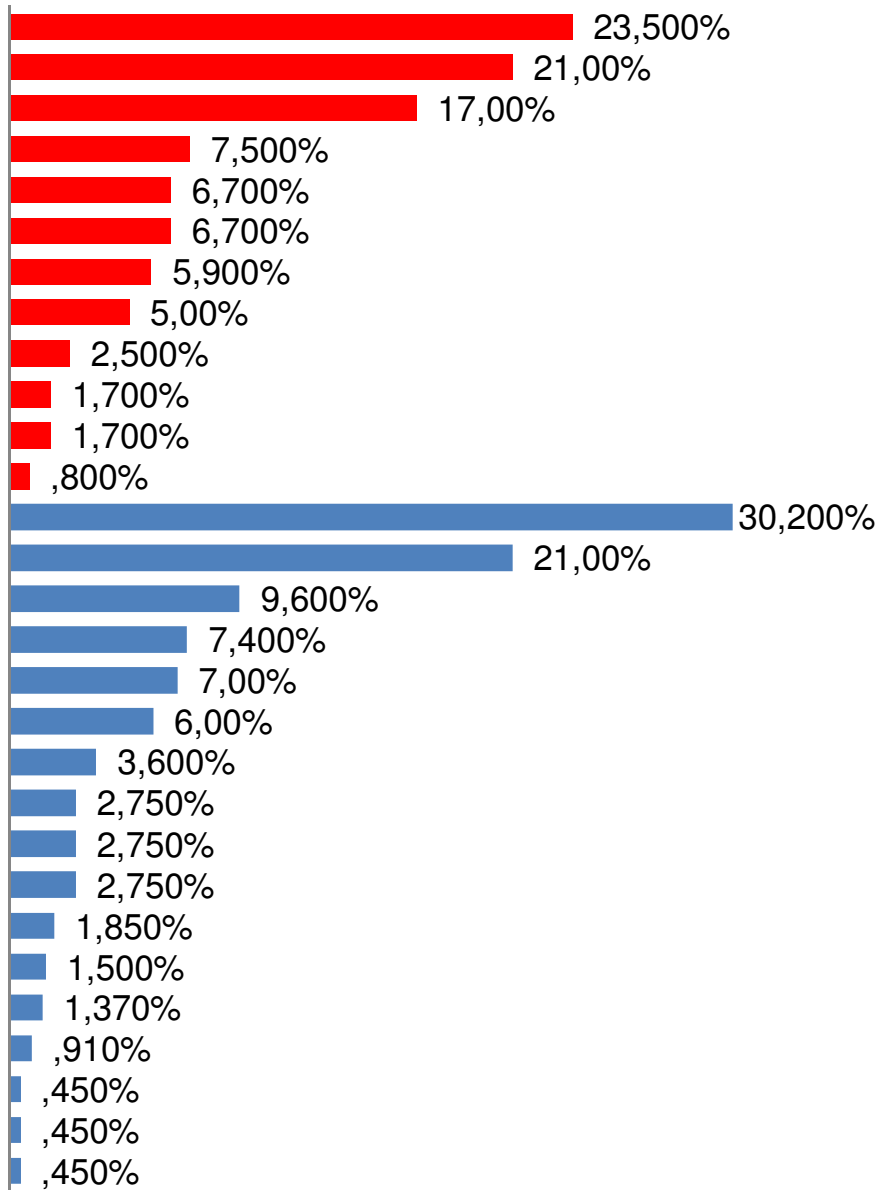 \\
\hline
\end{tabular}

Fonte: os autores.

\section{Trevo do Aeroporto}

A leitura comunitária (Fig. 11) aponta como aspectos positivos mais relevantes da área o seu valor simbólico (21,1\%), em função da sua imagem associada à Base Aérea e ao aeroporto; o valor estético do lugar (16,5\%), referente a visuais abertos e os eventos institucionais (12\%), novamente relacionados à Base Aérea. Como aspectos negativos 
principais têm-se o desconforto acústico (25\%), em função do ruído das aeronaves da Base Aérea; a má conservação (20\%) e a insegurança em relação ao tráfego (11\%). Destacamse algumas citações relativas ao principal aspecto positivo - valor simbólico - tais como: "marco do progresso de Camobi", "cartão postal da cidade", "representa o poder aéreo instalado em uma cidade de porte médio como Santa Maria, o que lhe dá importância no cenário nacional" [Base Aérea de Santa Maria]; "ícone representativo de boas-vindas da cidade" [Monumento da entrada da cidade]; "lembra automaticamente a Base Aérea, o que remete de imediato a Camobi, sendo um símbolo do bairro" [Monumento do avião da Base Aérea]. Já para o principal aspecto negativo desconforto acústico, os comentários nesse ponto nodal foram "barulho ensurdecedor dos aviões"; "treinamentos noturnos com as aeronaves incomodam um pouco" [Base Aérea de Santa Maria].

Figura 11: Ranking de aspectos positivos (azul) e negativos (vermelho) do ponto nodal Trevo do Aeroporto.

\begin{tabular}{|c|c|}
\hline $\begin{array}{r}\text { Desconforto acústico } \\
\text { Má conservação } \\
\text { Insegurança (tráfego) } \\
\text { Falta de significação para a comunidade } \\
\text { Não tem aspecto negativo } \\
\text { Restrita ao público } \\
\text { Pouco explorado paisagisticamente } \\
\text { Dificuldade de leitura do lugar } \\
\text { Abandono } \\
\text { Dificuldade na mobilidade não-motorizada } \\
\text { Dificuldade na mobilidade motorizada } \\
\text { Insegurança (criminalidade) } \\
\text { Falta de acessibilidade } \\
\text { Valor simbólico } \\
\text { Valor estético } \\
\text { Eventos institucionais } \\
\text { Valor histórico } \\
\text { Mobilidade motorizada } \\
\text { Marco referencial } \\
\text { Valor de memória } \\
\text { Valor sócio-cultural } \\
\text { Potencial de utilização }\end{array}$ & 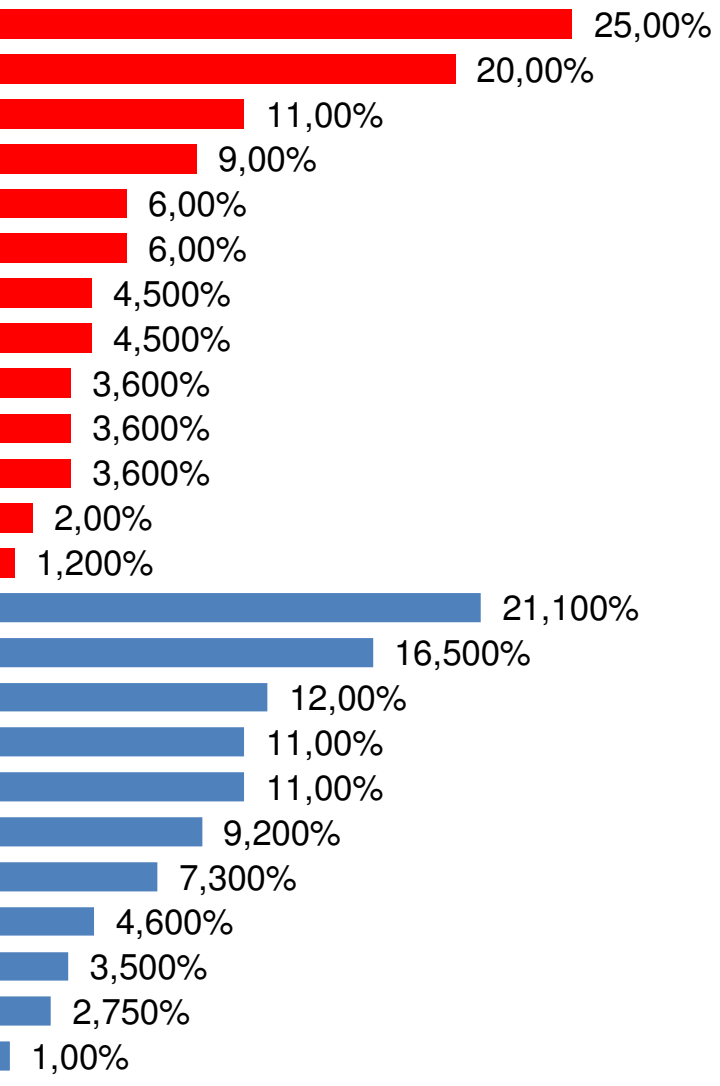 \\
\hline
\end{tabular}

Fonte: os autores.

\section{Avenida Roraima}

Na leitura comunitária (Fig. 12) prevaleceu como aspectos positivos o potencial de utilização da área para o lazer e recreação $(21,5 \%)$, o valor estético do lugar $(10,8 \%)$ e o valor simbólico (8\%). Já os aspectos negativos mais mencionados foram a má conservação $(26,6 \%)$, a pouca exploração paisagística $(17 \%)$ e a dificuldade na mobilidade motorizada 
(16,2\%). O principal aspecto positivo - espaço propício para lazer e recreação - foi detalhado por alguns respondentes como "atrativa tanto para caminhadas e andar de bicicleta, quanto para tomar um chimarrão e conversar"; "as pessoas circulam diariamente tanto para trabalhar como para passear" [Av. Roraima]; "a UFSM é o grande parque de Camobi"; "um lugar muito bom para passar um final de semana ensolarado" [UFSM]. Já o principal aspecto negativo - má conservação - foi ressaltado em comentários como "falta cuidado e manutenção do espaço" [Rótula da RS-509/ Av. Roraima]; "lixo acumulado"; " escuridão total no trecho entre as Faixas Nova e Velha" [Av. Roraima]; "as calçadas chegam a ser perigosas de andar"; "muitos prédios não recebem a devida manutenção"; "lixo espalhado" [UFSM].

Figura 12: Ranking de aspectos positivos (azul) e negativos (vermelho) do ponto nodal Av. Roraima.

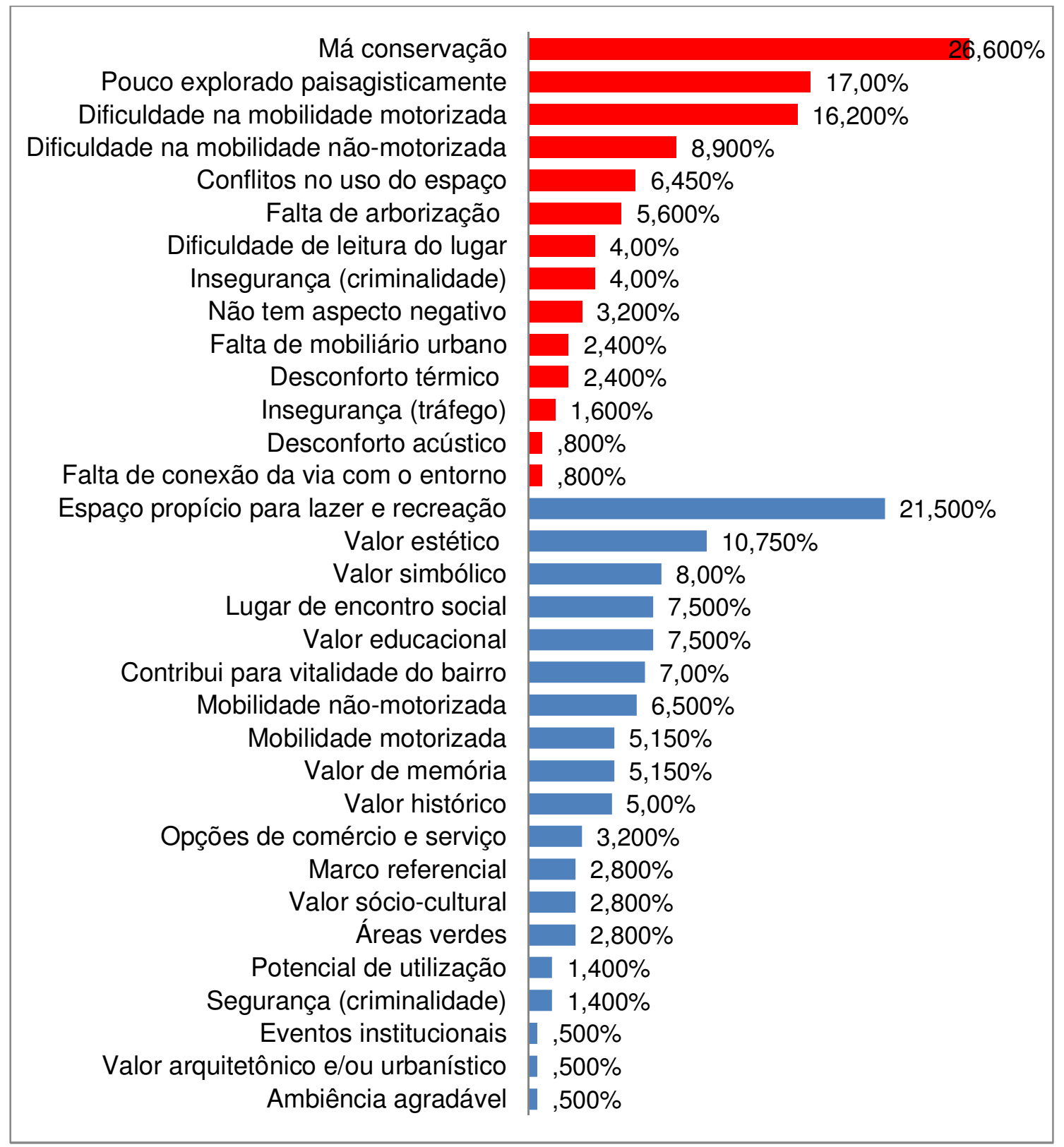

Fonte: os autores. 


\section{Centro Comercial}

A leitura comunitária (Fig. 13) aponta como aspectos positivos mais relevantes da área a ambiência agradável (24,5\%), referente aos interiores de algumas lojas; o valor simbólico $(15,2 \%)$, referente a associações imagéticas do canteiro central a vias de maior hierarquia e a áreas urbanizadas; e as opções de comércio e serviços (15,2\%). Quanto aos principais aspectos negativos, mencionam-se a má conservação (23\%), as dificuldades na mobilidade não motorizada $(20,5 \%)$ e a pouca exploração paisagística $(13 \%)$. Alguns comentários que evidenciaram o principal aspecto positivo citado pelos respondentes - ambiência agradável - foram "lugar aconchegante, tranquilo e que nos leva a fazer pequenas compras sem desgaste com trânsito" [Centro Comercial Camobi] e "restaurante e lojas acolhedores" [Restaurante e lojas de departamento]. O principal aspecto negativo - má conservação - foi evidenciado pelos comentários "pouco iluminado" [Centro comercial Camobi]; "normalmente está com a grama altíssima"; "deveria ser limpo com mais frequência" e "carece de manutenção" [Canteiro central da RS-509].

Figura 13: Ranking de aspectos positivos (azul) e negativos (vermelho) do ponto nodal Centro Comercial.

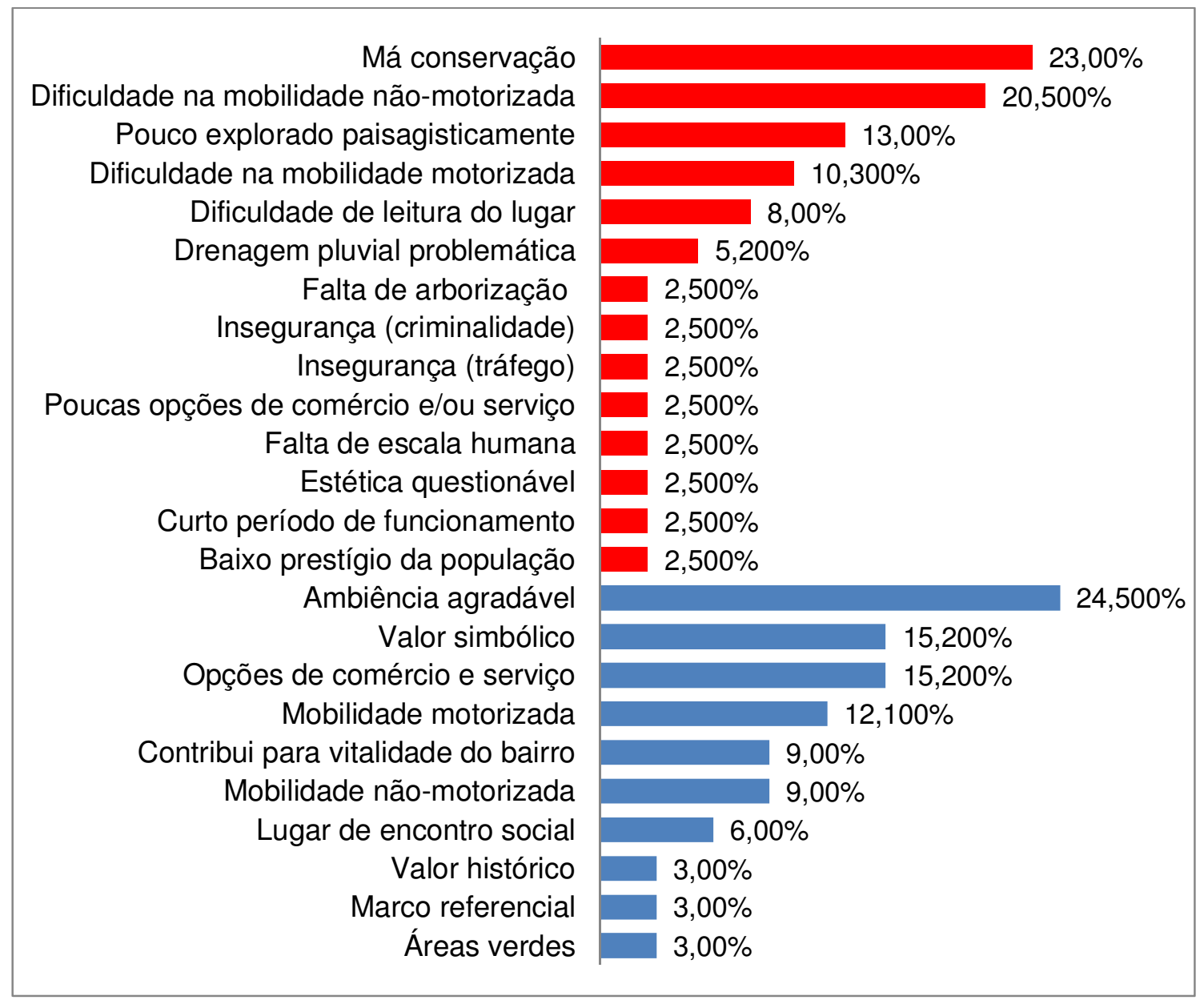

Fonte: os autores. 


\section{Igreja do Amaral}

Na leitura comunitária (Fig. 14) prevaleceram como aspectos positivos o valor de marco referencial (25\%), em função da igreja; as opções de comércio e serviço $(14,2 \%)$ e o valor histórico, também devido à igreja. Os aspectos negativos mais relevantes foram a pouca exploração paisagística $(30,7 \%)$, a dificuldade na mobilidade motorizada $(15,4 \%)$ e o baixo prestígio da população $(15,4 \%)$, referente à igreja. Alguns comentários que evidenciaram o principal aspecto positivo citado pelos respondentes - marco referencial - "é a referência que os moradores da Av. João Machado Soares dão para quem vem do centro 'na Faixa Velha, dobra à esquerda na Igreja do Amaral"; "demarca limites de um extremo ao outro de Camobi"; "único monumento religioso ao longo da Faixa Velha"; "ponto de referência da duplicação da Faixa Velha" [Igreja do Amaral]; "marca a área de início do bairro Camobi para quem vem do Centro" [Centro comercial e supermercado]. Reforçando o principal aspecto negativo - pouco explorado paisagisticamente - os comentários dos respondentes foram "poderia ter um maior destaque na paisagem, através de um tratamento paisagístico e luminotécnico"; "entorno pouco valorizado"; "entorno caótico e sem qualidade, compromete o uso e a valorização desse patrimônio religioso"; "poderia ser um ponto de referência mais forte, através de praças e paisagismo" [Igreja do Amaral].

Figura 14: Ranking de aspectos positivos (azul) e negativos (vermelho) do ponto nodal Igreja do Amaral.

\begin{tabular}{|c|c|}
\hline Pouco explorado paisagisticamente & $0,700 \%$ \\
\hline Dificuldade na mobilidade motorizada & $15,400 \%$ \\
\hline Baixo prestígio da população & $15,400 \%$ \\
\hline Má conservação & $7,700 \%$ \\
\hline Dificuldade na mobilidade não-motorizada & $7,700 \%$ \\
\hline Poucas opções de comércio e/ou serviço & $7,700 \%$ \\
\hline Estética questionável & $7,700 \%$ \\
\hline Curto período de funcionamento & $7,700 \%$ \\
\hline Marco referencial & $25,00 \%$ \\
\hline Opções de comércio e serviço & $14,200 \%$ \\
\hline Valor histórico & $12,500 \%$ \\
\hline Eventos institucionais & $12,500 \%$ \\
\hline Valor religioso & $8,900 \%$ \\
\hline Valor estético & $7,150 \%$ \\
\hline Lugar de encontro social & $7,150 \%$ \\
\hline Localização de fácil acesso & $7,150 \%$ \\
\hline Valor simbólico & $3,600 \%$ \\
\hline Valor de memória & $1,800 \%$ \\
\hline
\end{tabular}

Fonte: os autores. 


\section{CONSIDERAÇÕES FINAIS}

O Mosaico da Paisagem mostrou-se válido como instrumento de coleta das percepções ambientais a partir das imagens mentais da comunidade do bairro onde foi aplicado. A respeito do método, considerou-se fundamental a utilização do painel visual no momento de aplicação do questionário para que os respondentes reconhecessem os locais a partir de sua própria visão. $\mathrm{O}$ uso das fotografias facilitou a evocação das memórias e dos valores relativos aos lugares retratados, talvez mais do que se simplesmente os pesquisadores citassem os pontos nodais verbalmente. Entretanto, esse instrumento tem uso limitado, servindo para direcionar o questionário apenas quando há locais já definidos de interesse e que são de conhecimento prévio dos respondentes da pesquisa, dos quais se quer a leitura comunitária. Em outras situações, pode ser desejado que o respondente não tenha esse direcionamento visual prévio por parte do pesquisador, sendo mais adequado o uso dos tradicionais mapas mentais de Lynch (1997).

Sobre o questionário propriamente dito, percebeu-se como mais vantajosa a abordagem da comunidade através de formulário digital, pois houve uma adesão muito maior de respondentes no tempo estipulado quando comparada à dos questionários aplicados in loco, uma vez que há possibilidade do respondente participar no horário que le for mais conveniente e a garantia de anonimato perante o pesquisador. No entanto a aplicação presencial permitiu captar formas não verbais de expressão que auxiliaram no entendimento do estudo por parte dos pesquisadores. O contato direto com os respondentes permitiu também dirimir possíveis dúvidas sobre a pesquisa e seus produtos, aproximando a comunidade da academia.

Em relação aos resultados da aplicação, a leitura comunitária pode vir a fortalecer o planejamento urbano democrático do bairro, já que foi evidenciado o que os habitantes reconhecem como significativo para sua comunidade, ou seja, elementos que devem permanecer e serem valorizados na paisagem. Tanto os aspectos positivos quando os negativos mencionados para cada ponto nodal sugeriram estratégias de planejamento ou de projeto para aproveitar oportunidades e sanar os problemas identificados.

A partir dos resultados, o objeto empírico revelou-se como ausente de uma unidade imagética, não se enquadrando na definição de bairro proposta por Lynch (1997), como uma região dotada de uma unidade temática configurativa própria. Camobi, por sua extensão territorial e processo de origem, reflete uma diversidade maior de imagens, aproximandose da escala da pequena cidade, observada já na definição de cinco pontos nodais. Isso sugere que o Mosaico da Paisagem pode ser aplicado além da escala do bairro, sendo útil também para estudos na escala da cidade.

\section{REFERÊNCIAS}

AGÊNCIA DE DESENVOLVIMENTO DE SANTA MARIA. Santa Maria em dados. Santa Maria, 2016. Disponível em: http://santamariaemdados.com.br/sociedade/8-6-lazer-e-esporte/. Acesso em: 13 jul. 2016. 
ANGEOLETTO, Fabio; SANTOS, Jeater W.M.C. et al. Tipología socio-ambiental de las ciudades medias de Brasil: aportes para un desarrollo urbano sostenible. Urbe - Revista Brasileira de Gestão Urbana, v. 8, n. 2, p. 272-287, 2016.

ANGEOLETTO, Fabio; FELLOWES, Mark DE; SANTOS, Jeater W.M.C. Counting Brazil's Urban Trees Will Help Make Brazil's Urban Trees Count. Journal of Forestry, v. 116, n. 5, p. 489-490, 2018.

ATLAS SOCIOECONÔMICO DO RIO GRANDE DO SUL. Rede e hierarquia urbana. Disponível em: http:/ / www.atlassocioeconomico.rs.gov.br/rede-e-hierarquia-urbana Acesso em: 23 maio 2018.

CARMONA, Matthew; HEATH, Tim; OC, Tanner; TIESDELL, Steve. Public places - urban spaces: the dimensions of urban design. 2.ed. Oxford: Elsevier, 2010.

CASTRIOTA, Leonardo Barci. Patrimônio Cultural: Conceitos, políticas, instrumentos. São Paulo: Annablume, 2009.

CORRÊA, Roberto Lobato. O espaço urbano. São Paulo: Ática, 1989.

CULLEN, Gordon. Paisagem Urbana. Lisboa: Edições 70, 1993.

DEL RIO, Vicente. Introdução ao desenho urbano no processo de planejamento. São Paulo: Pini, 1990.

IBGE - Instituto Brasileiro de Geografia e Estatística. Estimativas da população dos municípios brasileiros com data de referência em $1^{\circ}$ de julho de 2014. Disponível em: http://www.ibge.gov.br/home/ presidencia/noticias/pdf/analise_estimativas_2014.pdf Acesso em: 27 maio 2017.

LYNCH, Kevin. ¿De qué tempo es este lugar?: para uma nueva definición del ambiente. Barcelona: Editorial Gustavo Gili, 1975.

LYNCH, Kevin. A imagem da cidade. São Paulo: Martins Fontes, 1997.

MACIEL, Filipe Bassan Marinho. Qualificação da paisagem urbana: uma proposta humanista para o bairro Camobi. Santa Maria, 2014. Monografia (Trabalho de Conclusão de Curso de Arquitetura e Urbanismo) Universidade Federal de Santa Maria, UFSM.

MACIEL, Filipe Bassan Marinho. Copresença em loteamentos residenciais dispersos de cidades médias brasileiras. Porto Alegre. 2018. Dissertação (Mestrado em Planejamento Urbano e Regional) - Universidade Federal do Rio Grande do Sul, UFRGS.

NASAR, Jack. The effect of sign complexity and coherence on the perceived quality of retail scenes. Journal of the American Planning Association, v. 53, n. 4, p. 499-509, 1988.

PORTEOUS, John Douglas. Environmental Aesthetics: ideas, politics and planning. London: Routledge, 1996.

RUMBLE, Heather; ANGEOLETTO, Fabio; CONNOP, Stuart; GODDARD, Mark A.; NASH, Caroline. Understanding and applying ecological principles in cities. In: LEMES DE OLIVEIRA, Fabiano; MELL, Ian. (Eds.) Planning Cities with Nature: Theories, Strategies and Methods. Amsterdam: Springer Nature, 2019. Doi:10.1007/978-3-030-01866-5.

SALAMONI, Gian Franco. O crescimento urbano por extensão e suas repercussões morfológicas em estruturas urbanas: estudo de caso: Santa Maria/RS. Porto Alegre, 2008. Dissertação (Mestrado em Planejamento Urbano e Regional) - Universidade Federal do Rio Grande do Sul, UFRGS.

SANTOS, Milton. Da totalidade ao lugar. São Paulo: Ed. USP, 2005.

SCHLEE, Mônica Bahia; NUNES, Maria Julieta; REGO, Andrea Queiroz et al. Sistema de espaços livres nas cidades brasileiras: um debate conceitual. In: TÂNGARI, Vera Regina; ANDRADE, Rubens de; SCHLEE, Mônica Bahia (Orgs.). Sistema de espaços livres: o cotidiano, apropriações e ausências. Rio de Janeiro: Ed. UFRJ, 2009.

SOARES, Beatriz Ribeiro. Pequenas e médias cidades: um estudo sobre as relações socioespaciais nas áreas de cerrado em Minas Gerais. In: SPOSITO, M.E.B. (org.). Cidades médias: espaços em transição. São Paulo: Expressão Popular, 2007. p. 461-494.

VOORDT, Theo J.M. van der; WEGEN, Herman. B.R. van. Arquitetura sob o olhar do usuário: programa 
de necessidades, projeto e avaliação de edificações. São Paulo: Oficina de Textos, 2013.

YÁZIGI, Eduardo. A alma do lugar: turismo, planejamento e cotidiano em litorais e montanhas. São Paulo: Contexto, 2001.

Data de submissão: 22/ fev./ 2019

Data de aceite: 20/ jul./ 2019 